\title{
Innovative activities for the development of the Mazovia region
}

\section{Magdalena Kiech}

\begin{abstract}
In the 2018 Bloomberg Innovation Index, Poland came in $21^{\text {st }}$ among 80 countries. In Poland, the five most innovative regions have been the same for three years. According to the Millennium Index 2018 - Innovative Potential of Regions these are regions with business and academic centres, characterised by developed scientific and R\&D foundations, which support the development of the region. The leading regions include Mazovia, Małopolskie, Pomorskie, Dolnośląskie and Lubuskie because that is where the best universities and research and scientific centres are located, which influences the development of human capital. If we think about the ecosystem of innovation, the triple helix model is worth mentioning, as it covers the mutual, complex relations which appear in the process of creating knowledge between three kinds of entities. The model includes scientific institutions (universities, R\&D centres, supporting institutions), industrial institutions (companies) and the public administration. In recent years, it has been posited that the model should also include the society, the institutions which represent it, such as non-governmental institutions, and final innovation recipients, i.e. citizens. This expanded version, called the quadruple helix model, advocates that the society be included in the innovation system, thus leading to new forms and models of organization, as well as a network of relationships between different stakeholders of the innovation process. The Regional Innovation Strategy (RIS) for Mazovia is a document which reflects the quadruple helix approach in the Mazovia region. The actions undertaken by the Mazovian regional authorities for the region's development in terms of innovation are in accordance with the strategic objectives included in RIS Mazovia. The document states that innovations can and should have the chance to appear and develop everywhere where there are innovative and enterprising people. The strategy's objectives tree also adopts a broad understanding of the environment for innovation, both in terms of the subjective and procedural aspect.

Key words: innovation, regional development, small and medium enterprises, start-up, smart specializations, services, regional innovation strategy, Mazovia, business environment institutions
\end{abstract}

In 2018 the Bloomberg Innovation Index assessed countries' innovativeness according to seven criteria, including research and development expenditure and the concentration of public companies from the high-tech sector. Poland came in $21^{\text {st }}$ among 80 countries which provided data to the ranking in at least six categories.

\section{High or low}

If we take into consideration that at the beginning of the classification process there were over 200 countries in the 2018 Bloomberg Innovation Index Ranking, Poland's ranking as $21^{\text {st }}$ in the world can lead to the conclusion that the country is climbing up the ladder of innovative countries. However, if we think about regional development, we should look more closely at the situation in each Polish region. The five most innovative regions in Poland have been the same for three years according to the Millennium Index 2018 - Innovative 
Potential of Regions. These are regions with business and academic centres, characterised by developed scientific and R\&D foundations which support the development of the region. The leading regions include Mazovia, Małopolskie, Pomorskie, Dolnośląskie and Lubuskie because that is where the best universities and research and scientific centres are located, which influences the development of human capital. However, in the case of Mazovia and Małopolskie, we can talk about an effect of synergy because of large urban agglomerations (Warsaw and Cracow), developed scientific foundations and the business sector. Expenditure on $R \& D$ activities speeds up the growth of innovativeness, leading to a rising position in the category of obtained patents.

\section{The innovation ecosystem}

To begin with, it is worth specifying what an 'innovation' is. The most popular definition is the one accepted by the European Union and the OECD. It originated in the Oslo Manual and states that an innovation should be understood as launching a new or significantly improved product or service, or implementing such a process, a new marketing or organization method in economic practice, workplace organization or relations with the environment. The new or significantly improved product is launched when it enters the market. New processes, organization methods or marketing methods are launched when they are used in business activities (Fig. 1).

\section{Quadruple-helix innovation:}

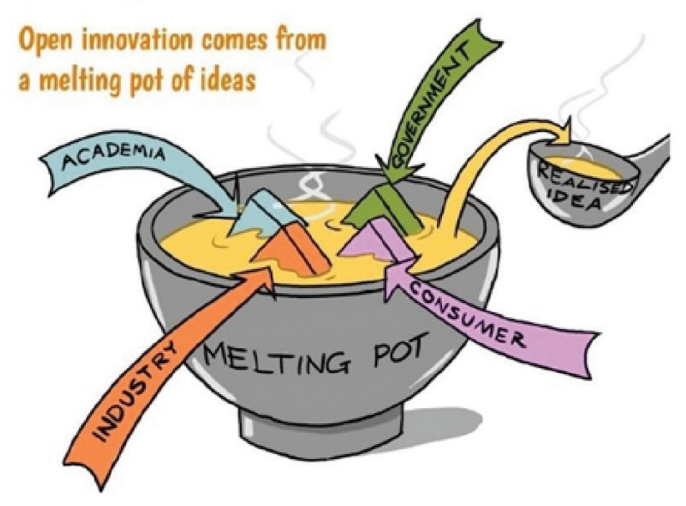

Fig. 1. 'Quadruple helix innovation'

Source: http://ec.europa.eu/digital-agenda/en/news/brorsalmelin-innovation-can-not-be-controlled, access 29.05.2015
Once we know what an innovation is, it is a good idea not to treat innovativeness as a synonym for innovations. When talking about the innovativeness of Polish companies, we usually have in mind implemented innovations. However, innovativeness should be understood in a wider context, as a peculiar characteristic of people open to new ideas and solutions, visible in their everyday life, professional activity, running a business. ${ }^{1}$

If we think about the ecosystem of innovation, the triple helix model is worth mentioning, as it covers the mutual, complex relations which appear in the process of creating knowledge between three kinds of entities.

\footnotetext{
${ }^{1}$ A passage from the Regional Innovation Strategy for Mazovia 2020, Warsaw 2015.
} 
The model includes scientific institutions (universities, R\&D centres, supporting institutions), industrial institutions (companies) and the public administration. When considering the innovative potential and ecosystem of a given region, we should take into account the potential for cooperation between its participants, because relations between these three groups of entities determine the transfer of knowledge and creation of innovations. In recent years, it has been posited that the model should also include the society, institutions which represent it such as non-governmental organizations and final innovation recipients, i.e. citizens. This expanded version, called the quadruple helix model, advocates that the society be included in the innovation system, thus leading to new forms and models of organization as well as a network of relationships between different stakeholders of the innovation process. The fourth helix emphasizes the importance of discoveries and innovations which improve citizens' comfort of living and enhance the society's well-being. In effect, this model helps shape relations between the participants of the innovation process, such as universities, national and local authorities, business and society. For this reason the quadruple helix model can be considered to be a model of innovative cooperation or an innovative environment in which universities, national authorities, companies and users of innovation cooperate to generate innovation.

\section{Regional strategies}

The Regional Innovation Strategy (RIS) for Mazovia is a document which reflects the quadruple helix approach in the Mazovia region. The first Regional Innovation Strategy for Mazovia (RIS Mazovia) was adopted in 2008. Its main aim was to create an innovation support system by, inter alia, building and maintaining cooperation networks and creating stable tools for supporting innovative activities. On the European level, the strategic concept for innovation development in the 2014-2020 programming period is outlined in the EU economic strategy - "Europe 2020" and a flagship initiative - "Innovation Union". In both cases one of the elements identified as essential is the need for regions to undertake direct actions supporting initiatives favourable to creating a business environment and stimulating companies' innovativeness which should lead to increasing their competetitiveness as well as that of the region. In response to such indications on the European level, in 2015 the updated version of RIS Mazovia was prepared. The Regional Innovation Strategy for Mazovia 2020, elaborated in accordance with the European Commission's guidelines, was updated to include strategies for smart specialisation which meant enhancing the role of stakeholders in programming, implementation, monitoring and evaluation.

\section{Smart specialisation}

The concept of smart specialisation focuses on concentrating knowledge resources and using them to implement a limited number of prioritised economic actions, to increase or maintain the region's competitive predominance in the world economy thanks to, inter alia, 
an economy of scale, broader market offer and increased productiveness. Smart specialisation allows local and regional authorities to direct their actions so as to let each entrepreneur better adjust to the region's general development vision. It is worth mentioning that this vision is formulated through an entrepreneurial discovery process (EDP) which is based on the active participation of representatives of the innovation ecosystem, including entrepreneurs, scientific institutions, public authorities, but also business support organizations such as training-consultancy centres, business incubators or technological innovation centres, technology transfer centres, science and technology parks or industrial parks, loan and guarantee funds. The policy of supporting innovation based on smart specialisation is intended to ensure the optimal use of public resources and to link them effectively with private capital. It is based mainly on cooperation with stakeholders - representatives of the scientific community, companies and business environment institutions. The role of the Mazovian regional government in this process is to create an innovativeness-enhancing system based on a network of cooperation and links between different institutions and development policy implementation instruments. At the same time, for private sector entities smart specialisation can be a source of information allowing them to undertake actions complementary to public intervention. The idea of smart specialisation can be perceived as a frame document serving to provide a thematic focus for research and innovation on a national or regional scale.

\section{Cooperation}

The main platform for cooperation between stakeholders and local/regional authorities in the Mazovia region are workgroups for smart specialisation (workgroups) and the Business Support Institutions Forum (BSI Forum). The combined effort of workgroup participants, including representatives of business, universities and institutions, cooperative links, clusters and science parks, resulted in the first list of priority directions of research for smart specialisation areas. The aim of the list was to direct support from the Regional Operational Programme for the Mazovia Region 2014-2020 (ROP MR 2014-2020) to B+R projects with potentially the most promising topics and research aims. Within this topic area, thanks to ROP MR 2014-2020, 441 million PLN has been allocated from the 571 million PLN (€131 million) available for Activity 1.2 "Enterprises' R\&D activity". ${ }^{2}$ The smart specialization workgroups have been taking part in a process of perfecting the support system within ROP MR 2014-2020 through a discussion about the criteria and assumptions of subsequent competitions.

The BSI Forum consists of representatives of business support institutions active in the Mazovia region. Organisations which cooperate within the BSI Forum are significant partners in a process of supporting RIS implementation. The aim of their representatives' cyclic meetings is to provide expertise and support in the processes of implementing RIS strategic aims concerning the development of pro-innovative activity as well as elaborating regulations concerning support for BSI. What is more, taking into consideration the role

\footnotetext{
${ }^{2}$ Own data from allocation monitoring conducted by the Regional Development and European Funds Department of Marshal`s Office of the Mazovia Region.
} 
of rank-and-file processes in creating solutions and strategies concerning innovation development, the participants of the BSI Forum are involved in the discussion leading to formulating the premises of the Mazovian regional government's projects and actions dedicated to the innovation system, such as competitions for start-ups, cluster policy development and international projects.

\section{Actions in favour}

Once we know what innovation is and who creates it, we can take a closer look at the actions undertaken by the Mazovian regional authorities for the region's development in terms of innovation. The essence of such actions is the role of the regional authorities in the innovation ecosystem, i.e. fostering and moderating cooperation between stakeholders, indicating directions of regional development and providing systemic solutions which boost social activity, develop competences and help to implement procedures favourable to innovations.

The undertaken actions are in accordance with the strategic objectives included in RIS Mazovia. The document states that innovations can and should have the chance to appear and develop everywhere where there are innovative and enterprising people. The strategy's objectives tree also adopts a broad understanding of the environment for innovation, in terms of both the subjective and procedural aspect. That is why RIS Mazovia includes five strategic objectives which define the need for the region's activity in the field of innovation, as well as operational objectives which show how the strategic objectives are to be achieved.

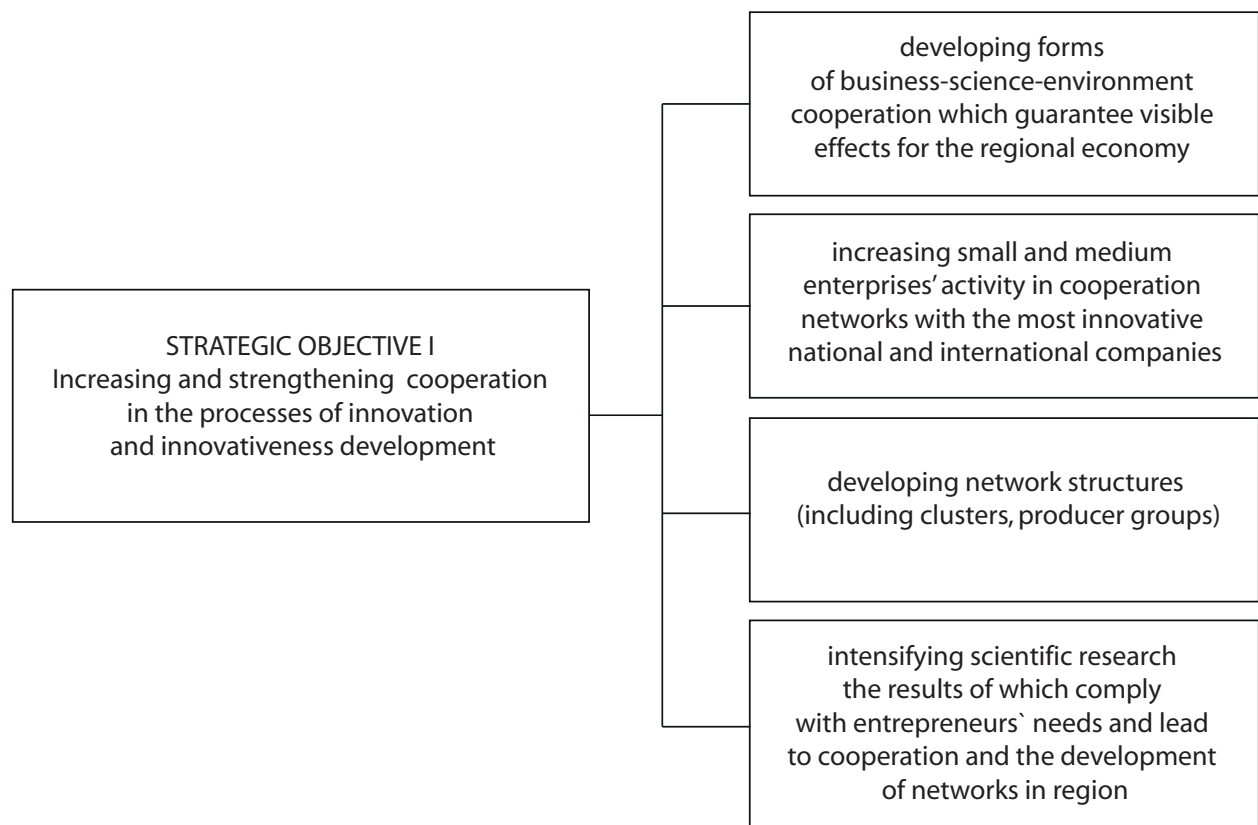




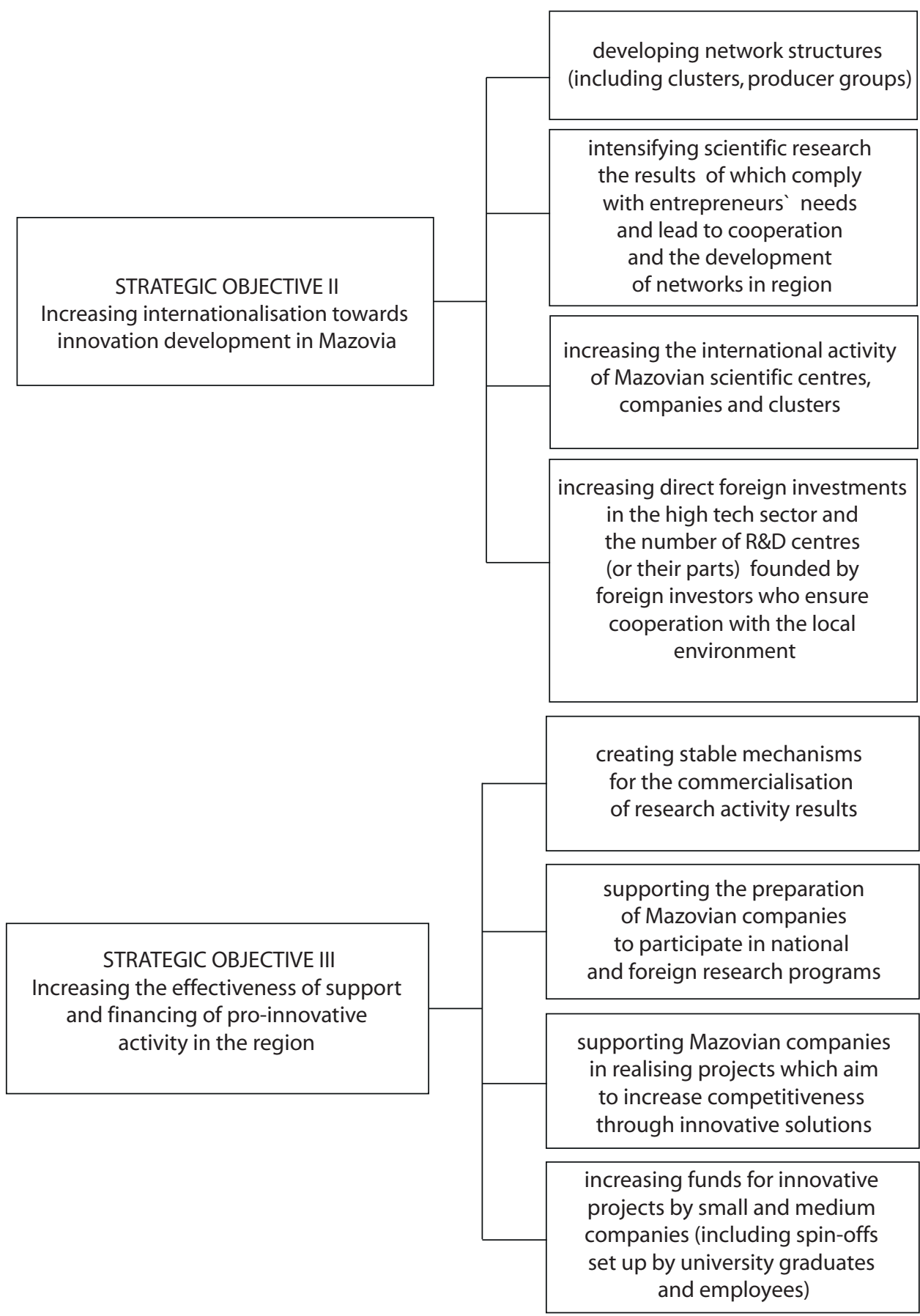


STRATEGIC OBJECTIVE IV

Fostering and promoting pro-innovative and entrepreneurial attitudes contributing to creativeness and cooperation effectively promoting entrepreneurial attitudes conducive to innovativeness and supporting initiatives which promote best practice in Mazovian companies and institutions concerning effective use of instruments supporting innovation

increasing the activity of the Regional Government of Mazovia in building a network promoting Mazovia as an innovative region

supporting the building of social trust and social capital among Mazovian economic entities

promoting attitudes and initiatives contributing to initiating and implementing social innovations in the region

supporting the implementation of information and communication technologies in companies

supporting the creation and implementation of smart management systems and e-services (e-administration, e-health, e-logistics, e-finance, e-trade, e-work, e-education)

Information society development supporting initiatives which promote broader access to and use of the Internet

fostering digital technologies skills and digital inclusion 


\section{Business support institutions}

The scale of undertaken actions is extensive. Due to legal circumstances, regional authorities base their strategic objectives mainly on cooperation with institutions operating for the development of entrepreneurship and innovation. These entities are called business support institutions - they do not operate to generate profit or they allocate their profits to pursuing statutory objectives in accordance with the statute or equivalent document. ${ }^{3}$ They have the material and technical basis, human resources and competences necessary to provide services for the small and medium enterprises sector (SMEs). Among these institutions there is a vast spectrum of entities which influence how commercial economic entities function. Among the most often mentioned types of BSI are training and consultancy institutions, which offer technical infrastructure and financial support to companies. There are also public administration institutions which function at the intersection of administration and business. ${ }^{4}$

BSIs are treated as an element which fills the gap between market mechanisms and public administration activities. They are the infrastructure which accelerates development processes and enterprise development strategy implementation. Taking this into account, the Regional Government of Mazovia has implemented an accreditation system for Mazovian BSIs to ensure a proper and appropriate level of services provided by BSIs to small and medium enterprises and financed partly from public funds (through ROP MR 2014-2020 or the Act on Public Benefit and Volunteer Work [ustawa o działalności pożytku publicznego i o wolontariacie]). The aim of the system is to integrate these institutions and improve their qualifications by providing requirements taken from system criteria and monitoring rules. Thus the regional government contributes to developing relations between BSIs and entrepreneurs, where the essence of BSI services is answering to the individual needs of small and medium enterprises while maintaining a high level of service quality and flexibility.

The Mazovian BSI accreditation system includes open catalogues of BSI profiles and a classification system of specialized pro-development services. Descriptions of BSI generic profiles have been elaborated on the basis of a broad analysis of available literature and descriptions of best Polish and foreign practice. The profiles were chosen according to the classification system of Innovation and Enterprise Centres in Poland, elaborated by experts preparing a report on innovation centres published by the Polish Agency for Enterprise Development (PARP). ${ }^{5}$ Ten kinds of activity were chosen as fundamental in each area and requiring stable institutional rebuilding to function in the market.

\footnotetext{
${ }^{3}$ Surplus profits are used in this case for institutional development and providing more services for the SME sector, and not for fulfilling other needs of the institution's owners.

${ }^{4}$ Expert analysis for the Marshal's Office of the Mazovia Region Accreditations system of Mazovia BSI providing prodevelopment consultancy services of specialised character.

${ }^{5}$ Ośrodki innowacji i przedsiębiorczości w Polsce. Raport 2012, A. Bąkowski, M.Mażewska (eds), PARP, Warszawa, p. 12.
} 
1. Consultative-Training Centres,

2. Business Incubators,

3. Academic Business Incubators,

4. Innovation Centres,

5. Technology Transfer Centres,

6. Technology Incubators,

7. Science and Technology Parks,

8. Industrial Parks,

9. Loan Funds,

10. Credit Guarantee Funds.

However, all areas of activity as well as business and supplementary processes which appear in a developed enterprise were taken into account to describe the classification system of specialized pro-development consultative services. 11 thematic groups of services concerning each area of enterprise activity were defined on this basis.

The implemented solution allows the system of accreditation to also be used to involve accredited BSIs in other areas of regional development support, under the condition of fulfilling additional requirements concerning the instruments necessary to realise all the necessary tasks.

\section{Calls for proposals}

One area in which accredited BSIs, as well as other entities, can participate are open calls for proposals within ROP MR 2014-2020. Within Priority Axis III "Development of innovative potential and enterpreneurship, Activity 3.1 Promoting the development of small and medium enterprises in Mazovia, Subactivity 3.1.2 Small and medium enterprises' development", two calls for proposals were announced:

1. Supporting the running and development of enterprises - through consultation vouchers - Small and medium enterprises are the beneficiaries, whereas BSIs realise prodevelopment consultative services, which can be paid for with consultation vouchers. The aim is to increase the competitiveness of the small and medium enterprises sector in terms of strategy elaboration, business monitoring, technology transfer and forecasting. The premise is that enterprises will use advanced and specialized consultancy services in the area of: launching new products/services, including specialised laboratory, measurement, diagnostic, certifying services, product testing, technology testing, service-improving management (logistic processes optimisation, automatization of document circulation), marketing analyses, financial-economic analyses, elaboration and launching of enterprise development strategies based on new technologies or innovative solutions. The minimal value of a subsidy was 10,000 PLN, the maximum value was 70,000 PLN. The value of the voucher is 50,000 PLN. 
2. Supporting the initial phase of enterprise development - BSIs are the beneficiaries, whereas small and medium enterprises are the target group. The BSIs should have experience in providing services to entrepreneurs with technological potential aiming to implement technological innovations in the initial phase of their development, i.e. up to 24 months since registration. Support will be provided for BSIs with experience in enterprise incubation and acceleration helping economic entities in their initial phase of development. The maximum subsidy for one project was 2,500,000 PLN, the minimum was 100,000 PLN.

Moreover, within this subactivity, a non-competitive project "Modelling an innovation offer system" was launched, wherein BSIs are the recipients. They can take part in a grant competition by offering to create or modernise pro-innovative services. The project aims to model the system of pro-innovative offers, i.e. ones of higher quality and suitable to the needs of small and medium enterprises. As a result, new complex services will be launched. This effect will be achieved by transferring the range of services into innovation processes. Such an approach to supporting small and medium enterprises will allow them to gain a competitive advantage as a result of pro-innovative changes introduced as a result of received services. The project includes actions supporting the creation and implementation of new services, such as networking or reporting meetings serving to maintain stable communication between grantees as well as between grantees and potential recipients of their services. 400,000 PLN is the predicted average subsidy for one complex service.

All the above forms of support within ROP MR 2014-2020 are in accordance with RIS Mazovia's strategic objectives. This means they are activities by the regional government contributing to Mazovia's innovativeness and development. The essence of such actions is providing the participants of the innovation ecosystem, especially entrepreneurs, with the possibility of receiving support which can move them forward in the development on the local and international market and enable them to start implementing innovative solutions in their organisation. Such support can take the form of suitable consultancy services, adopting a demand-based approach (adapting to recipients' needs), which can be very helpful in overcoming potential barriers in the process of innovation implementation by entrepreneurs. This year's Deloitte "Corporate research and development" report indicates that the biggest problem in the research and development support system, indicated by $29 \%$ of enterprises, is identifying the R\&D activity which qualifies for support. This is partly the result of unclear regulations and interpretations by entities engaged in providing support for R\&D activity. In effect, qualified services can come in helpful when defining the activity to qualify for support. As was the case in 2016, enterprises indicate the availability of diversified support $(63 \%)$ and qualified research staff $(62 \%)$ as the main factors which can lead to an increase in investments in research and development. ${ }^{6}$

\footnotetext{
${ }^{6}$ A passage on the basis of Research and Development in enterprises' Report https://www2.deloitte.com/pl/pl/pages/ zarzadzania-procesami-i-strategiczne/articles/innowacje/ce-corporate-research-development-report.html
} 
An answer to the need for varied support was the ROP MR 2014-2020 call for proposals in Priority Axis I "Economic exploitation of R\&D activity", Activity 1.2 Enterprises' RED activity, intended to enhance $R \& D$ activity taken up by entrepreneurs. The increase of expenditure on R\&D activity and, as a consequence, a better position in the category of patents granted is an indicator of innovativeness in the region. Such competitions, in which entrepreneurs are the beneficiaries, include the following types of projects.

1. Innovation vouchers - support will be directed to actions which aim to realise research defined by the entrepreneur in cooperation with a scientific institution, serving to prepare a new product or service, design project, production technology or a significant improvement of the final product or production technology;

2. $R \mathcal{E} D$ projects - support covers scientific research, industrial research and development activities, including preparing prototypes, demonstrations, pilot projects, testing and validating new or improved products, processes or services in an environment which is a model of real conditions, which aim to further technically improve products, processes or services, and the final shape has not yet been defined. Support is also available for development of technology (developed or purchased by the entrepreneur) which has not yet been commercialized and used in economic activity. In particular, funding will include expenditure on further R\&D phases serving to complete or adjust the technology to the enterprise's specific requirements. Support within an $R \& D$ project can also be directed towards:

- purchase by an entrepreneur of research infrastructure necessary to conduct planned R\&D works;

- acquiring industrial property protection rights and implementing them as well as conducting patent clearance analyses which are necessary for the effective commercialisation of technologies. Gaining industrial property protection is not a necessary element of the project.

3. Creating or developing an RED base - support is directed towards enterprises' creating and developing R\&D bases for their innovative activity through investment in equipment, technology and other necessary infrastructure leading to the creation of innovative products and services. The offered support is to lead to the creation of R\&D centres by enterprises, hence funds for infrastructure will be granted only if the enterprise presents plans concerning R\&D activity. It will also be possible to gain and implement industrial property protection (excluding expenditure concerning applying for a patent, functional pattern or industrial pattern) as well as conduct a patent clearance analysis necessary for the effective commercialisation of a technology. It is also acceptable to acquire support for a project's preparatory phase and management during the whole project realisation process including external consultations.

4. Process of experimenting and searching for development and innovation niches (nonprofiled competition) - support is directed towards enterprises' R\&D projects in areas different than the region's smart specialisations, excluding activities which aim to develop existing technology. 


\section{Financial support and mindset promotion}

The regional government authorities have been implementing initiatives in favor of innovation development which are funded from the regional government's own funds and are dedicated to young companies and scientists. The aim of such activities is to implement business solutions and scientific works which are innovative in their field. What is more, the regional government authorities have been promoting Mazovia's support ecosystem startups, seeing in them a desired element of a competitive market. Among these actions the following can be distinguished:

1. Mazovia Innovator contest - since 2008 the contest has been promoting forwardthinking practices of young scientists and entrepreneurs from Mazovia. The main aim of the competition is to select young talents in science and enterprise and to promote proinnovative attitudes in the region. There are two categories: "Young Innovative Company" and 'Young Innovative Scientist'. New solutions used in enterprises, which improve work organisation while paying attention to human capital and the environment, are appreciated. Also recognized are young scientists whose doctoral theses are essential for the development of science in Poland and globally. The laureates are young, creative people who consequently strive to reach targets and succeed thanks to the use of innovation.

2. Start from Mazovia contest - the aim of the competition is to promote Mazovia's startup support ecosystem and choose the start-ups which present the most interesting solutions. Registered companies can take part in the competition if they have been running a business in Mazovia to produce new products and services for between one and three years before the date when the competition was announced. The assessment process serves to select start-ups with attractive innovative formulae, high growth potential, and successes in implementing innovative economic solutions (services, products).

3. Creating Mazovia's start-up support ecosystem through funding for acceleration programmes contest - the aim of the competition is to choose acceleration programmes directed to start-ups active in the fields specified as Mazovia's smart specialisations. The acceleration process allows young entrepreneurs to acquire new abilities and competences while mentoring support will allow them to specify their business ideas. All this will speed up the development of their companies/business projects and increase their chances of introducing the proposed solutions to the market. The competition is realised on the basis of the 2018 Annual Program of Cooperation between the Regional Government of Mazovia and NonGovernmental Organizations and Other Public Benefit Entities which specifies the support of activity enhancing economic growth, including enterprise development, among the priority areas of cooperation.

These initiatives fit into current trends and the market's needs, as can be seen in support programs directed towards start-ups, co-funded by the European Union at the national level, such as Scale Up and Start in Poland are the result. The need for innovation persists and subsequent young entrepreneurs have been looking for help in achieving market success. It is worth remembering that to create a start-up ecosystem one should search for solutions best 
suited to a given market, taking into consideration the local culture, business environment, key areas of the economy and competences. One's own strengths should be defined while observing the actions of other countries before choosing the solutions appropriate to one's own country.

This aspect was taken into consideration when selecting the laureates and runnersup among start-ups in the first edition of the "Start from Mazovia" competition, so that the selected initiatives would be the answer to real problems in the region. Among those awarded, the following young companies deserve attention:

1. BACTrem - the main prize for a patented bioremediation vaccine and products and services which enable cleaning an environment contaminated with oil-derivatives and heavy metals. The biotechnologies prepared by BACTrem can be used in the bioremediation and degradation of toxic substances, household sewage treatment (eliminating xenobiotic contamination, i.e. toxic substances, pharmaceuticals and heavy metals), composting or agriculture - to eradicate plant pathogens from the soil, biodegrade harmful pesticides, facilitate decay of organic matter of animal and plant origin or in the market of agricultural waste treatment.

2. SOLACE - winner of the second prize for creating an all-year house which generates more energy than it consumes. What is more, all its parts are packed in one container which is brought to the owner. Thanks to the use of renewable energy, exploiting the house does not generate the contamination present in the case of traditional construction. $80 \%$ of the materials used can be recycled. The usable floor area is $48 \mathrm{~m}^{2}$ - including an entresol (ground floor $-32 \mathrm{~m}^{2}$ ). This is the minimum program, however it is enough to have a hall, living room, bedroom, kitchen and bathroom. All the devices in the house are supplied with energy from solar panels which suffice to provide the necessary energy all year long. Surplus energy can be sold. The building is equipped with a two-way counter which enables the user to profit from sending energy to the network. Heat insulation guarantees a leakage rate at the level of $\mathrm{NF}<15 \mathrm{kWh} / \mathrm{m}^{2} /$ year, which means the heating costs can be lowered byr even $70 \%$. The house can be inhabited in Europe for the entire year.

3. Codepeak - winner of the third prize for a platform which enables the user to integrate internet shopping in different e-commerce platforms. DigitalPeak is a tool directed to sellers of digital products, such as: software license keys, game keys, e-books. It serves to automatize the sending of electronic items as well as facilitate simultaneous selling and sale management on numerous platforms (i.e. Allegro, Ebay, WooCommerce, Magento and many other, less popular e-commerce platforms). The managing panel delivered by DigitalPeak enables all the platforms to be controlled from one place. Thanks to a common base of products, sellers can check which platforms generate the biggest turnover and, in the proper time, introduce changes serving to gain increased sales.

4. Scanye - runner-up for solutions using AI and machine learning, which help to reduce working hours dedicated to accountancy, paying invoices, archiving documents and performing other related processes. OCR text-recognition technology is enhanced by novel algorithms which interpret data and return the necessary information, regardless of 
the document's format. This application saves thousands of working hours in accountancy offices throughout Poland, speeding up entering an invoice in the books even 8-fold. The company focuses on extraction and interpretation of data from invoices for the needs of accountants. A dedicated application and access by API are available. It is an important element of the 15-minute factoring process delivered by SMEO and the automatic entering of documents to the platform for small and medium enterprises E-Biz by OTP.

There are a lot of competitions in the national market which select the best and the most promising start-ups. They are one among numerous ways of stimulating development and new ideas which can be transformed into promising businesses. The essence of modelling such support is choosing companies which are eager to stay in the region and work in favour of its development while expanding onto foreign markets. The local innovation system should primarily contribute to creating the space for implementing different ideas, reforms and services, experimenting, enhancing entrepreneurship, creating an innovation culture and - most importantly - risk taking.

The above-mentioned activities have been chosen from the catalogue of actions contributing to the creation and strengthening of the regional innovation system, ensuring conditions for development and networking cooperation between entrepreneurs, the administration and scientific institutions. This allows these activities to be considered ones which contribute to the development of Mazovia. It should be remembered that innovative activity carries with it significant risk. Not every new idea can be implemented, not every implementation brings the expected profits, and each success is preceded by numerous attempts. That is why a strategic approach to development should popularise innovative activity, allowing it to achieve critical mass, resulting in the creation of stable relations and mechanisms of knowledge commercialisation - independent from public intervention. ${ }^{7}$

\footnotetext{
${ }^{7}$ A passage from the Regional Innovation Strategy for Mazovia 2020, Warsaw 2015.
} 
III. Miscellaneous / Varia

\section{Działania innowacyjne na rzecz rozwoju województwa mazowieckiego}

\section{STRESZCZENIE}

W rankingu Bloomberg Innovation Index w 2018 r. Polska uplasowała się na 21. miejscu na 80 krajów. Z kolei w „Indeksie Millennium 2018 - Potencjał Innowacyjności Regionów” pierwsza piątka najbardziej innowacyjnych województw w Polsce pozostaje niezmienna od trzech lat. Stanowią ją regiony skupiające duże ośrodki akademickie i biznesowe, dla których cechą wspólną jest rozbudowana baza naukowa oraz badawczo-rozwojowa, która wspiera rozwój innowacyjności regionów. W gronie liderów mamy województwa: mazowieckie, małopolskie, pomorskie, dolnośląskie oraz lubelskie. Myśląc o ekosystemie innowacji warto wspomnieć o Modelu Potrójnej Helisy (Triple Helix), który obejmuje wzajemne złożone relacje zachodzące w procesie tworzenia wiedzy pomiędzy trzema rodzajami podmiotów. W ramach modelu wyłoniono ośrodki naukowe (uniwersytety, ośrodki badawczo-naukowe, instytucje wspierające), przemysł (przedsiębiorstwa) i administrację publiczną. W ostatnich latach zaproponowano uwzględnienie w tych relacjach społeczeństwa i instytucji go reprezentujących, jak np. organizacje pozarządowe oraz końcowych użytkowników innowacji, tj. obywateli. Mówimy wówczas o Modelu Poczwórnej Helisy, który sprzyja włączeniu społeczeństwa w system innowacji, co prowadzi do pojawienia się ich nowych form i nowego sposobu organizacji, sieci powiązań między różnymi interesariuszami procesów innowacji. Dokumentem odzwierciedlającym poniekąd podejście Modelu Poczwórnej Helisy w województwie mazowieckim jest Regionalna Strategia Innowacji dla Mazowsza. Podejmowane działania przez władze regionalne na Mazowszu na rzecz rozwoju regionu w obszarze innowacji, co do zasady wpisują się w cele strategiczne ujęte w RIS Mazovia, która zakłada, że innowacje mogą i powinny mieć szanse powstawać oraz rozwijać się wszędzie tam, gdzie są przedsiębiorczy i innowacyjni ludzie. Drzewo celów strategii uwzględnia też rozumienie środowiska dla innowacji możliwie szeroko, zarówno pod względem podmiotowym, jak i procesowym.

Słowa kluczowe: innowacja, rozwój regionalny, małe i średnie przedsiębiorstwa, start-up, inteligentne specjalizacje, usługi, regionalna strategia innowacji, Mazowsze, instytucje otoczenia biznesu

Magdalena Kiech, Unit of Regional Innovation System, Department of Regional Development and European Funds of the Marshal's Office of the Mazovia Region.

Magdalena Kiech, Wydział Regionalnego Systemu Innowacji, Departament Rozwoju Regionalnego i Funduszy Europejskich Urzędu Marszałkowskiego Województwa Mazowieckiego. 